\title{
Motiverte turnusleger starter i allmennpraksis, men blir de værende?
}

\begin{abstract}
Det har lenge vært en uttalt bekymring blant tillitsvalgte om at rekrutteringen til allmennmedisin ikke er god nok.
\end{abstract}

Bekymringen gjelder særlig for allmennpraktikere ute i distriktene (1). Økt behov for allmennleger i fremtiden er begrunnet med økt arbeidsmengde, høyere gjennomsnittsalder blant allmennleger og behov for bedre legedekning i distriktene (2). Ifølge Legeregisteret har det vært en økning $i$ antall allmennleger de siste årene, men andelen allmennpraktikere har ligget ganske stabilt på ca. $24 \%$ av den samlede legestanden de siste årene (personlig meddelelse fra Anders Taraldset, Legeforeningen).

I en undersøkelse gjennomført av LEFO Legeforskningsinstituttet i 2015 ba vi 292 turnusleger om å oppgi, på en skala fra 1 (ikke motivert) til 5 (svært motivert), hvor motiverte de var til å jobbe med indremedisin, kirurgi, psykiatri, allmennmedisin og andre spesialiteter i fremtiden (3). Én av fire turnusleger $(25,3 \%)$ svarte at de var svært motiverte for å jobbe med allmennmedisin i fremtiden.

Ett år senere, i 2016, viste Legeregisteret at $25,7 \%$ av legene i den samme kohorten faktisk jobbet $\mathrm{i}$ allmennmedisin. Men hvor mange av disse blir værende?

\section{Ytre rammevilkår}

Dersom tilflyt av nye leger i allmennpraksis virker lav, kan det altså ikke forklares med rekrutteringsproblemer. Utfordringen må være å legge forholdene til rette slik at allmennpraktikerne liker seg og ønsker å fortsette. Her er nok ytre rammevilkår vel så viktig som interesse for faget.

Resultatene fra en nylig publisert ph.d.studie fra Universitetet i Tromsø viser at jobbtilfredshet, muligheter for faglig utvik-

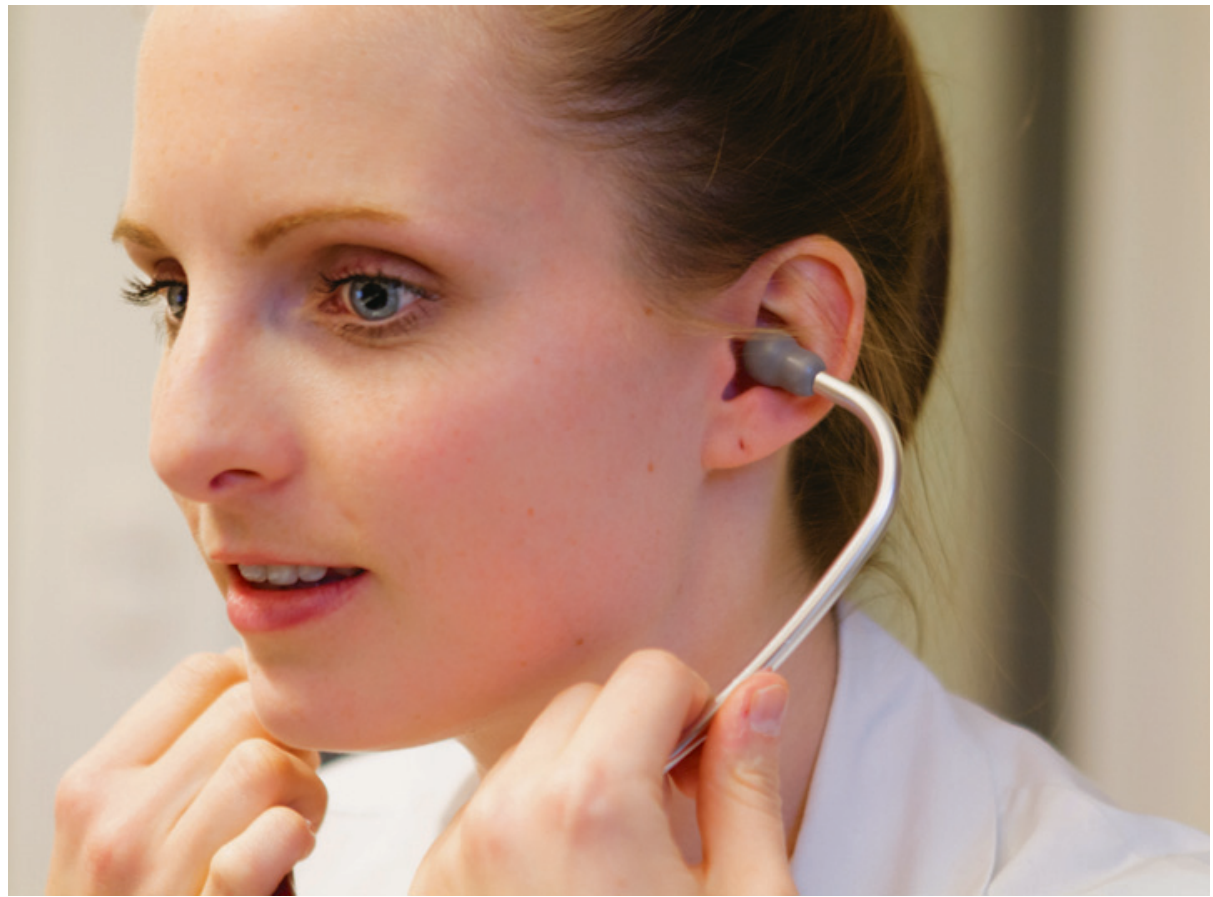

Illustrasjonsfoto: Ole Kristian Losvik

ling, personlig autonomi og kontroll over egen arbeidstid er viktigere enn økonomiske incentiver, og vil antagelig i større grad bidra til at legene fortsetter $i$ allmennmedi$\sin (4)$.

\section{Cecilie Birkeli}

LEFO - Legeforskningsinstituttet

\section{Litteratur}

. Sollien K. Fastlegene flykter fra distriktene. Dagens Medisin 1.2.2016. http://dagensmedisin. no/artikler/2016/02/01/fastlegene-flykter-fradistriktene/ (2.6.2016).
2. Westnes SL, Kristoffersen ES, Burman RA. Fastlegeordningen trenger flere leger. Tidsskr Nor Legeforen 2012; 132: 674-6. http://tidsskriftet.no/ article/2237928 (2.6.2016).

3. Birkeli CN. Nasjonal evaluering av turnustjenesten for leger 2015. Oslo: LEFO - Legeforskningsinstituttet, 2015. http://legeforeningen.no/Emner/ Andre-emner/Publikasjoner/Rapporter/Nasjonalturnusevaluering-for-leger-2015/ (2.6.2016).

4. Holte JH. Remuneration and organization in general practice: Three essays on doctors' preferences. Troms $\varnothing$ : Universitetet i Troms $\varnothing$ - Norges arktiske universitet, 2015. http://munin.uit.no/handle/ 10037/8259 (2.6.2016). 